\title{
The Jew Uncut: Circumcising Holocaust Representation in Europa Europa
}

\author{
Jeffrey E. Wolfson
}

check for

updates

Citation: Wolfson, J.E. 2021. The Jew Uncut: Circumcising Holocaust Representation in Europa Europa. Humanities 10: 64. https://doi.org/ 10.3390/h10020064

Received: 28 January 2021

Accepted: 27 March 2021

Published: 7 April 2021

Publisher's Note: MDPI stays neutral with regard to jurisdictional claims in published maps and institutional affiliations.

Copyright: (C) 2021 by the author. Licensee MDPI, Basel, Switzerland. This article is an open access article distributed under the terms and conditions of the Creative Commons Attribution (CC BY) license (https:// creativecommons.org/licenses/by/ $4.0 /)$.
Holocaust and Genocide Education, Texas Holocaust and Genocide Commission, Austin, TX 78701, USA; j.e.wolfson@thgc.texas.gov

\begin{abstract}
Film adaptations invariably yield insights into their written source material, at least to the extent that they elect to translate or omit what may be deemed the literature's essential components. This is certainly the case for director Agnieszka Holland's 1990 film, Europa Europa, which adapts Solomon Perel's account of surviving the Shoah. By drawing on discourse in Holocaust studies and adaptation studies, and by examining the film adaptation's points of alignment with what Perel records in his memoir, I argue that Europa Europa resists the dominant trend of de-Judaizing the Shoah in artistic representation. Europa Europa privileges explicitly Jewish content and an unmistakably Jewish point of view by focusing on the theme of circumcision. In doing so, the film succeeds in highlighting how the Shoah was, at its core, a campaign to annihilate not just the Jewish people, but also the longstanding principle of the Jewish covenant with the Eternal, as embodied by circumcision. Through its cutting and reshaping of the memoir's details, Holland's film seeks to establish a covenant with the viewer to bear witness to the Jewish spirit of the survivor's testimony. The film presents a model for representing the Holocaust in art, a model that masterfully defies the de-Judaization of society that the Nazis envisioned and tried to make real.
\end{abstract}

Keywords: Holocaust; survivor memoir; film adaptation; Jewish identity; covenant; circumcision

Film adaptations invariably yield insights into their written source material, at least to the extent and in the manner that they elect to translate what may be deemed the literature's essential components. In this essay, I will examine the curious and sometimes daring ways in which director Agnieszka Holland's (1990) theatrical release, Europa Europa, adapts the story of Solomon Perel, who, as a Jewish teenager, survived the Shoah by adopting various unlikely disguises, including that of a Hitler Youth. Special attention will be accorded to how Holland's film takes care to privilege the theme of circumcision, which is a far less conspicuous narrative element in the memoir that Perel published in 1990.

Because most writings on Holland's film have largely ignored the circumstances of Perel's experiences as related in the memoir, they have underestimated Holland's changes and have therefore typically been content to concentrate on topics far removed from circumcision. The present study approaches the two works from a different angle, that of adaptation; that is, it scrutinizes differences and similarities between the memoir and the film. Through their affirmations of Jewish religious identity in the context of the Nazi campaign to annihilate it, the two works find their most pronounced alignment and their most profound messaging about the Shoah. Paradoxically, it is mainly by cutting and refiguring much of the survivor narrative that Holland conveys the Jewish essence of Perel's testimony and formulates a covenantal relationship between the survivor and the filmgoer.

By focusing on Holland's treatment of Perel's experience, I will demonstrate that an adaptation can render immense changes upon its source material while still doing justice to its spirit; in this case, an unabashedly Jewish spirit. Europa Europa's accomplishment in endorsing a Jewish-centered perspective of the Shoah-that is, in looking through a lens that privileges circumcision as the theological covenant that is traditionally situated at the 
heart of Jewish male identity - has too often gone unappreciated. Art has tended to distort the Final Solution by universalizing the Nazis' fundamentally antisemitic intentions and crimes. Both Holland's film and Perel's memoir resist this trend towards de-Judaization, if by different means.

This is no small thing. If Alon Confino is correct to write that the annihilation of the Jews in the Shoah first depended on the very idea of "a Germany, and later a world, without Jews" entering the German imagination as a real possibility (Confino 2014, p. 9), then today's artist seeking to depict the Shoah must recognize the danger of de-Judaizing its history for public consumption. In such a light, it becomes clear that Europa Europa's achievements are evident in how it dares to depict and revisit the circumcision of its protagonist and also in how it constructs a model for how artists adapting a survivor account can successfully utilize a recognizably Jewish theme when engaging a general audience. Moreover, it is striking that Europa Europa not only moves circumcision to the forefront of the Holocaust narrative, but frames circumcision as a positive attribute by the film's end, as we shall see. As scholars such as Sander Gilman and Jay Geller have examined in depth, circumcision has not been widely seen in this way, but rather as a hideous flaw or as an indication of deeper flaws (such as feminization or disease) within the Jew (Gilman 1991, p. 119; Geller 2007, pp. 26-28). By bucking longstanding canards concerning circumcision, Holland's film effectively circumcises Holocaust representation, masterfully cutting and reshaping its narrative and characterizations along the lines of Jewish identity and purpose.

The key questions guiding this examination include the following: What is entailed in the survivor's call to bear witness? What are the deeper meanings and ethical implications of how the circumcision motif factors into Holland's response? What makes the film's blatant alterations of facts found in the survivor account "kosher"? Finally, how might the artist's circumcision-centered response present a useful and respectable model for others hoping to represent the Shoah in art?

The choice of artistic adaptation as a topic is particularly fitting for any study of how to approach the literary representations that mean to commemorate what was lost in the Shoah. By cutting, rearranging, recharacterizing, and otherwise altering material, the process of adaptation from one artistic medium to another inevitably depends on and signifies acts of violence on a source text. As Millicent Marcus writes in apparent celebration of the most extreme examples of this practice, "Death of old forms and rebirth into new ones is, of course, a way of talking about adaptations, especially the transgressive adaptations that destroy as they create, challenging and subverting the authority of their textual models" (Marcus 1999, pp. 301-2). Yet, these words must resonate differently when the artist treats direct testimony by a survivor of the Shoah, for such material explicitly and implicitly speaks to acts of violence committed against not only the Jewish body, but also the Jewish presence and voice.

Holocaust survivor accounts, virtually without exception, attempt to use their voices to bear witness to the effects of the Nazi assault on the Jew and to deny any message of ultimate rebirth or palliative transformation in its aftermath. This sort of denial already transgresses against artistic norms and audience expectations, particularly in American culture. By "challenging and subverting the authority of their textual models" in the manner Marcus lauds of other examples of adaptation, the survivor's testimony regarding the Shoah will be obscured. Adapters treating Holocaust survivor accounts thus run the risk of aiding the Nazi goal of silencing the already brutalized voice of the Jewish victim and surviving witness. In this respect, the violence of adaptation becomes an act of violation that thwarts the ethical imperative of bearing witness to the Shoah.

This is not to say that an adaptation is ethically bound to match its source material point for point, even when the subject is the Shoah. Film and literature are inherently different, so one can never replicate the other; of course, even were it possible, replication would be a meaningless pursuit for an artist. Discerning which features of the source material are crucial to translate into the other medium presents to the adapter a daunting 
task. This remains true no matter what the chosen medium, but film is perhaps where there is the most at stake. For one thing, films often reach larger audiences than do books. In an era witnessing a proliferation of Holocaust denial, there is increased pressure on the filmmaker to communicate that which is accurate and essential-in a word, authentic. However, what are the ethical parameters for telling the Jew's story in an authentic way?

In The End of the Holocaust, Alvin Rosenfeld contends that the popular understanding of the Shoah has been twisted and abused to the point where it bears little resemblance to historical reality. He writes that "the Holocaust becomes broadly acceptable only as its basic narrative undergoes change of a kind that enables large numbers of people to identify with it. At the core of this process of transformation and identification lies the fate of the victims and survivors - their memories, stories, and future status as imagined figures within a continually evolving narrative of the crime against the Jews" (Rosenfeld 2011, p. 1). The artist's role in what Rosenfeld calls "this process of transformation and identification" is not to be underestimated, especially when too many depictions of the Shoah fail to strive for historical accuracy and appropriate focus on the purposeful victimization of the Jews. In ethical terms, Rosenfeld is correct to assert that an authentic understanding of the Shoah necessarily confronts the fate of the Jews within a narrative of the crimes against them.

Rosenfeld is hardly alone in recognizing that there are ethical boundaries to how Holocaust memory is shaped. Edward Isser (1997, p. 20) and Berel Lang (2000, p. 74) argue that the transmission of Holocaust memory demands an adherence to the basic facts of the historical narrative. Similar to Rosenfeld, other scholars urge that representations of the Shoah must never ignore that it was, at its core, the War Against the Jews. As Ilan Avisar writes, the basic facts of the history "concern the unequivocal identification of the victims as Jews .... . [and should foster an understanding of the Holocaust's] monumental injustice to the Jewish people" (Avisar 1988, pp. 181-82). In a similar vein, "The complexity of the artist's obligation to Holocaust material begins from the moment that material is engaged," writes Robert Skloot (1988, p. 19). He continues: "Two historical events inform all discussion of Holocaust drama. First, the destruction of six million Jews ... is an incontrovertible fact. Second, these victims were killed by the German nation under Hitler" (p. 71). Any art that includes a narrative of events in the Shoah should maintain fidelity to the victimization of the Jewish people and culture by the Nazis and their accomplices. Simply put, the extent of de-Judaization at play is a key measure of a representation's authenticity.

By minimizing, trying to justify, or otherwise denying Jewish suffering from Nazi crimes for the sake of entertainment or financial profit, too many film adaptations of Holocaust literature have ushered their audiences away from any meaningful confrontation with the purposeful effort to annihilate not just the Jew, but also Jewish tradition. This confrontation is the very thing that survivors came back to demand through their memoirs, so that others may come to bear witness. As Primo Levi instructs, "everyone" should be led to understand the "sinister alarm-signal" that Nazism represents (Levi [1958] 1996, p. 9). Film adaptations that elect to excise the impetus for the ethical reckoning that constitutes the essence of survivor accounts reduce Jewish anguish to cheap entertainment, especially when they refrain from naming that anguish as Jewish. They place the viewer in the Nazi mindset, which amounts to a callousness for the suffering of real human beings, beginning, but never ending, with the Jews whose testimonies are ignored. This is not to say, however, that every film adaptation of a survivor account must be a doomed enterprise when measured on the scales of ethics. Similar to a literary memoir, a film has tools at its disposal that may transmit the call to bear witness to the Shoah. Europa Europa is an example of this call being made effectively by a film adaptation.

Perel's memoir, Europa, Europa, was originally published in French in 1990, the same year that saw the release of Holland's film. ${ }^{1}$ Production of the film was in motion before

\footnotetext{
1 The reader will note the subtle difference between the titles of the memoir and the adaptation. The former includes a comma, while the latter does not. Even so, many of the secondary sources that refer to the book and film use the titles interchangeably. Adding to the confusion is that the book's cover omits the comma, though its title page does not. To avoid confusing the reader, this essay will typically avoid referring to the memoir by name.
} 
the memoir was published. As Perel writes, influence went in both directions between the survivor-memoirist and the filmmaker; Holland even helped shape the title of the memoir by describing her perception that his unlikely story of survival in certain ways resembled Voltaire's novel, Candide and Elia Kazan's film, America America (1963) (Perel [1990] 1997, p. xii). Unsurprisingly, the memoir and the film share some similar plot points and characters, but the differences are at least as important. This is particularly true of how Jewish themes, particularly circumcision, are treated in each text.

However, most scholarly writings on Europa Europa have largely overlooked its expansion of the circumcision theme and its effect on how Perel's biographical details are rendered on the screen. This oversight is surprising, for the spotlight on circumcision makes Europa Europa stand out, not only from Perel's memoir, but from other films. Circumcision is seldom mentioned, let alone depicted, in the genre of Holocaust films, which has demonstrated a general tendency towards de-Judaizing the Shoah. Furthermore, filmmaking has a history of generally ignoring male genitalia except in a comedic or romantic context, so it bears noting when a dramatic film goes to great lengths to portray the subject instead in a context of theological significance. For these reasons, Europa Europa's repeated references to circumcision are surely too conspicuous to be minimized or ignored.

Yet, scholars such as Annette Insdorf (2003, p. 330), Judith Doneson (2002, p. 200), and Yosefa Loshitzky $(1997$, p. 3) focus on other points of criticism, undervaluing the point that Europa Europa's breakthrough as a representation of the Shoah is found in its attention to the circumcision motif. Two scholars who succeed in moving the discourse in that direction are Lawrence Baron, who cites Perel's book and at least briefly refers to a few of the film's plot points involving circumcision (Baron 2005, pp. 84-88), and Omer Bartov, who notes that the film depicts circumcision as an unremovable marker (Bartov 2005, p. 139). However, both authors stop short of noting that the film's emphasis on circumcision places it at great distance from what Perel writes in his account.

A brief summary of Perel's memoir is now in order. Born in Germany in 1925, on 21 April, a day after Hitler's birthday, the text's Solomon ${ }^{2}$ enjoys his childhood with his parents, older brothers, and older sister. Rising antisemitism in the 1930s compels the family to move to Minsk. When the Germans and Soviets launch their invasions of Poland in 1939, Solomon flees eastward, is placed in a Soviet orphanage, and, for a time, becomes a devoted Stalinist. He flourishes as a student and stays in contact with his parents, whose situation deteriorates. Once the Germans attack the Soviets, chaos erupts in and around the school, and Solomon is eventually captured by Wehrmacht troops. Telling them that he is an ethnic German orphan, he wins them over with his German fluency and joins their unit as a translator and unofficial mascot. He is increasingly terrorized by his realization that his new friends will murder him in cold blood should they learn that he is a Jew by uncovering his circumcision. For over a year, he fights alongside the Germans. Due to his age, he is sent to a Hitler Youth school in Germany, where he spends three years and thrives academically and socially. However, he must go to great lengths to hide his Jewish background from his viciously antisemitic schoolmates and girlfriend. Missing his loved ones to the point where he is willing to risk his life to see them, he makes a failed attempt to visit his mother, father, and sister in the Lodz ghetto. He returns to school and survives additional close calls, during which the Germans almost discover his identity. At the war's end, he visits his hometown neighbors and concentration camps in an attempt to find his family. Eventually, he learns that his father starved to death in the ghetto, his sister was shot on a death march, and his mother was gassed in a truck near Chelmno and dumped into a mass grave. After finding his brothers, Solomon finally moves to the British Mandate of Palestine.

The reader of the memoir is immediately made aware of Solomon's Jewish identity and, soon after, of the Nazis' murderous views and policies regarding this identity. Very

2 To help avoid confusion, this article will refer to the survivor-memoirist as "Perel," the protagonist in the book as "Solomon," and the protagonist in the film as "Solly." 
early on, the author defines "the Shoah ... [as] the systematically planned murder of the European Jews, [which] would profoundly convulse our history" (Perel [1990] 1997, p. 2). The reader will be explicitly and frequently reminded that the Holocaust was specifically the Nazis' War against the Jews (pp. 99-100, 133, 146, 165, 190-91). Solomon frequently marks his Jewish identity, including references to the Passover Seder (p. 38), the holiday of Simchas Torah (p. 69), sabbath observance (p. 148), the Shema (p. 190), Hatikvah (pp. 195, 203-4), and the Hebrew language (pp. 209, 216). The frequency and variety of these references attest that the book is steeped in Jewish religious observance and culture.

All the same, circumcision is not featured often or at length in Perel's memoir. The main passage (Perel [1990] 1997, pp. 74-77) about the topic describes how Solomon, desperate to keep secret his Jewish background while hiding amidst Nazis, attempts to use a string to recreate his foreskin. Over the course of several days, this creates an infection, so he removes the string. "Without any treatment," Perel records, "the inflammation began to fade and eventually it disappeared completely" (p. 77). The whole affair, buried on pages near the center of the book, yields little consequence and is unlikely to prompt much reflection on the part of the reader with regard to the Jewish covenant with the Eternal.

Holland transforms this briefly described scenario into a longer, more detailed illustration of pointedly Jewish suffering and despair. Consistent with Perel's account, the filmic Solly (Marco Hofschneider) fears exposure as a Jew and decides to use a thread to restore his foreskin. Physical anguish renders him barely able to walk for the next several days. He even wets his bed. In what is arguably Europa Europa's most shocking and memorable image, the camera abruptly presents a closeup of the character's penis, which the thread has disfigured to the point of discoloration and infection. This is a significant moment, in that the film prompts a gasp from the audience without ever having to depict mass murders or a gas chamber. The unexpected visual of the teenager's infection in no way encompasses all Jewish suffering at the hands of Nazi perpetrators during the Shoah, but it highlights in graphic terms the notion that Nazi anti-Judaism was more than an abstract principle. On the screen, Solly removes the string, effectively unbinding his genitalia and accepting that the sign of the covenant is not to be undone.

As Omer Bartov writes about this portion of the film, "Thus Solly's circumcision becomes his last barrier to his desire to merge; or seen differently, it serves precisely the role for which it was intended by protecting his Jewish identity even when he is entirely willing to give it up" (Bartov 2005, p. 139). Holland makes it clear that Solly does not mutilate his penis to reject Judaism. He simply wants to live. ${ }^{3}$ The Jewish character's terror in exile from home and family has now culminated in a willingness to abuse the body from which death at the hands of the Nazis can be the only escape. Through the horrific image of the mutilated Jewish penis, Europa shakes the viewer from the slumber of apathy and depicts the Shoah in terms of agonizing violence on an intimate scale-violence in which the Jew is compelled to partake, and which is meant to sever the holy bond between him and his God. As in the memoir, the protagonist's penis heals, though the viewer will likely need longer to recover from the unsettling spectacle.

While the mutilation scenario has some basis in the memoir, Europa Europa's several other references to circumcision may be fairly categorized as inventions by the filmmaker. Examining some of them will be sufficient to establish a pattern in the film, one that commences at the start of the narrative. In the film's first moments, the viewer hears Hinei Mah Tov, a traditional song celebrating Jewish brotherhood, while witnessing baby Solly's circumcision ceremony. The moment also notably includes the character Solly's first use of voiceover narration, as he makes the incredible statement, "You won't believe this, but I remember my circumcision." Because Jewish law mandates that the covenant of circumcision, or briyt milah, be performed when a son is eight days old, the audience cannot be expected to accept these words at face value. Something deeper is meant, especially in

3 To accentuate this notion, the film inserts a brief scene where Solly draws a Star of David on a window, but then wipes it off. He remains a Jew at heart, just one doing all he can to survive. 
light of how the memoir makes no reference to the claim or even to the ceremony. What is it that Solly remembers?

Howard Eilberg-Schwartz explains that "circumcision is not an arbitrary sign of the covenant ... but a symbol that alludes directly to the substance of God's promise ... to multiply Abraham's seed. It is no accident that the symbol of the covenant is impressed on the penis. The penis is the male organ through which the genealogy of Israel is perpetuated" (Eilberg-Schwartz 1992, p. 23). From the start of the film, then, Holland employs circumcision as a plot point that is consistent with traditional Jewish teaching about Jewish continuity and higher purpose; this is to say that, in marked contrast to Nazism, whose racist worldview assesses human life to nothing more than matter, Judaism calls on the Jew to teach that human life has intrinsic value beyond matter, as defined by God. This is what the covenant evokes and why circumcision is central to Jewish identity and meaning.

As David Patterson writes, "In Hebrew the expression 'to make a covenant' is karat briyt, which literally means 'to cut a covenant.' This phrase clearly has its associations with the sign of the Covenant, which is circumcision, but it is also linked to an inscription of the Covenant, to a 'writing' of the Covenant into the flesh and onto the heart ... . [as a] summons" (p. 8). Patterson's highlighting of the briyt as a summons towards ethical behavior has profound meaning for how Holland elects to engage the audience. Europa Europa's choice to commence with a circumcision scene amounts to a summons for the viewer to bear witness to what will later play out on the screen. With Solly's intriguing if seemingly absurd words about remembering his own circumcision serving as the film's introduction, Holland harnesses the Holocaust survivor's voice to demand from the very start that the audience view him as a Jew and recognize that circumcision will be the defining factor in his struggle to survive. As Hal Hinson writes, "This is both an actual and a metaphorical occasion, a branding, and it reverberates throughout the entire film, washing it with blood" (Hinson 1991, p. D1). The film immediately compels the viewer into a reckoning with the idea that circumcision is something to be remembered, and not just by the survivor.

Europa next depicts the eve of Solly's bar mitzvah, which also brings to the forefront the circumcision motif. While his doting mother playfully readies the sabbath meal with the aid of his older sister, Bertha (Marta Sandrowicz), Solly relaxes in the bathtub. Suddenly, a brick tossed through the window frighteningly announces the unleashing of Kristallnacht, the huge pogrom that tore through synagogues and Jewish-owned homes and businesses throughout the Reich. This scenario is nowhere to be found in Perel's memoir, which offers no description of the bathtub, Kristallnacht, or Solly's bar mitzvah. Moreover, it is telling that Europa adjusts Solly's bar mitzvah to coincide with the great pogrom. Kristallnacht occurred in November of 1938. In the previous scene depicting the briyt milah, Solly's voiceover states that he shares Hitler's 20 April birthday. However, the memoir's first line reads, "I was born on 21 April 1925, in Peine, a town near Brunswick in Germany" (Perel [1990] 1997, p. 1). Later, the book repeats that Hitler's birthday is a day before Solomon's (p. 182). Holland's alterations of dates are not random; there is significance to her linking of Kristallnacht to the bar mitzvah, and her application of the circumcision motif to the bathtub scenario will help define that connection.

Observant Jews know to mark a son's bar mitzvah when he turns thirteen. In other words, the character of Solly cannot have been born in April (whether on the 20 or 21) and now have his bar mitzvah on 9-10 November, the dates of the pogrom. Because few in the audience are likely to be Talmudic scholars, this particular inconsistency is inconsequential, except to show that Holland places higher priority on the overall depiction of the Shoah than on fidelity to the details of Perel's life. This falls within the ethical parameters that were discussed earlier in this article: changes to Perel's biographical details are acceptable, even commendable, so long as the changes help to illustrate the core crimes of the Shoah. In this instance, the adaptation's change to Perel's story serves to spotlight the Shoah's cruel disruption to religious Jewish life, both personal and communal. Bar mitzvah signifies the 
transition of the Jewish male to adulthood, wherein he is obligated to follow the traditional precepts of the faith. It is a joyous occasion that marks the Jew's coming of age. However, for the character of Solly, as for other Jews confronted with the Nazi assault, familiar patterns of life that are tied to religious tradition must stop. On the eve of the destruction of European Jewry, the bar mitzvah can no longer signify a holy initiation to manhood.

Solly's situation in the bath at the launching of Kristallnacht is where the circumcision motif is reintroduced to the viewer. As Patterson writes, "In the ritual of bathing the body, then, one finds an affirmation of the life of the soul" (Patterson 1998, p. 173). When the brick flies through the bathroom window, Solly jumps up in panic. In his sudden, abrupt movement, he flashes his genitalia before the camera. It can be no accident that Holland draws a visual parallel between this scene and the previous one depicting the briyt. These are the first two moments where, no doubt to the audience's surprise, the character's circumcised penis is revealed, though one is a moment of peace, and the other, of rupture. Holland now uses the exposed, circumcised penis to signify the Jew's vulnerability at the onset of the Nazi assault. While Western cultural expectations would assert that the transition to manhood involves an assumption of power and strength, the Nazi attack means to rob the Jew of this capability.

In another departure from the memoir, the nude Solly escapes the house through the broken bathroom window, only later to return to a home in disarray. Standing amidst broken objects and overturned furniture, his beleaguered mother greets him. Solly's father bangs his own head repeatedly against the dining room table, the same table that moments before was laden for a festive Jewish meal in honor of Solly's impending maturation. In the pogrom's aftermath, Bertha's lifeless body now lies atop it, a huge gash in her head. Bertha's corpse atop the family table beside her bereaved father's weeping head should be acknowledged as an outstanding example of what Rosenfeld calls the "brilliant images" that lend power to Holocaust art (Rosenfeld 1980, p. 80), and it is purely Holland's creation.

As Perel relates in the memoir, the real Bertha was killed by a bullet while on a death march near the end of the war (Perel [1990] 1997, p. 206). In its departure from the historical account to portray Bertha's brutal death on the eve of Solly's bar mitzvah, the film calls attention to the sudden destruction of the Jewish family and home, beginning with the murder of a Jewish child. However, there is to be no mistaking that the film portrays the pogrom as more than an attack on Jewish homes and children, but also on the religious covenant that assigns them a purpose. It must be noted that Europa punctuates the pogrom with visible reminders that the covenant is under assault: the attack begins with the camera shot of Solly's exposed, circumcised penis and ends with the shot of Bertha's corpse upon the bar mitzvah table. The fractured table holding the corpse may even be interpreted as a signifier of the circumcised genitalia attached to the Jewish Solly, who is now marked for annihilation, not maturation. From this point until Europa Europa's final moments, circumcision keeps Solly's safety in question, as Holland will again and again remind the audience.

In another scenario that points to circumcision as a sign of the Jew's vulnerability, Solly has fled the Soviet orphanage following the surprise German invasion. Now captured by German soldiers, he is lined up alongside Russian prisoners. He watches in fear as the Germans separate Jewish and political prisoners from the others. The communist prisoners hurry to destroy their identification papers. By contrast, Solly hesitates, tucks his papers in the front of his underwear, and tells the Germans that the papers are lost. The placement of these papers against Solly's circumcised penis can apparently be credited to Holland's imagination, because it never happens in Perel's memoir. As Perel writes, "With the heel of my shoe I dug a little hole in the soft soil, shoved the telltale papers into it, and tamped the earth back down. All this under the guard's nose" (Perel [1990] 1997, p. 19). However, the film director's placement of identity papers against the Jew's genitals can only mean to remind us that circumcision is the core of the Jew's identity and the basis of the Nazis' grounds for murder. As if to reinforce the audience's awareness of this danger, in the next moment, the Germans drop another character's pants and then execute him. As Solly sur- 
vives and finds opportunities to don unlikely disguises, Holland serves up reminders that it is his Jewish identity alone that marks him for death. While befriending German soldiers who have no idea that he is Jewish, Solly provides a voiceover explanation to the viewer: "That's when I was first confused about identity. Who were my friends and enemies? How could they be nice to me and kill others? What set us apart? A simple foreskin?"

In the memoir, Solomon dreams that the Germans have finally seen through his disguise and know he is a Jew. As Perel writes, "The worst that could have happened: Screaming wildly, they pounced on me with unbridled frenzy, tore me limb from limb, and impaled my head on a flagpole" (Perel [1990] 1997, p. 107). In the film adaptation's depiction of a nightmare by Solly, Holland presents a twist on the protagonist's fear of discovery. The dream sequence witnesses Solly's return to his family home in Germany, where his relatives, including Bertha, are alive and gathered at the Passover seder table. After dining on hard-boiled eggs dipped in salt water-traditional seder foods that symbolize growth and tears-most of the family members seem to ignore Solly and exit the room. Solly ends up hiding in a closet alongside a terrified Hitler, who fears that his own circumcision will be exposed. The peculiar scenario of Jewish family members silently abandoning a returning loved one at the seder table is every bit as strange as finding a circumcised Hitler in the closet of a Jewish home. Passover is a festive holiday, not a silent or solemn one. In the paradigm rendered by Europa, circumcision possesses the power to create a bond between the Jew and the Führer himself, even to inspire fear in the monster. From this perspective, Holland may be seen to hint to Solly that even in the Shoah, circumcision contains the Jew's seed of strength, not just vulnerability.

As the earlier summary indicates, the end of Perel's memoir recounts that after liberation, Solomon ultimately moves to the British Mandate of Palestine. Solly's voiceover is put in the privileged position of uttering the film's final spoken words, just as earlier it had uttered the film's first spoken words. In both instances, it refers to the Jewish covenant of circumcision. The mention of Solly's sons in this context is important, though wholly absent from the memoir.

In his final words to the audience, Solly says via voiceover: "From that moment on, I decided to be only a Jew ... . And when I had sons, I barely hesitated to circumcise them." In a nod to the film's opening scene depicting the briyt milah, the song Hinei Mah Tov is once again played. This time, however, the camera discloses that the real-life Perel, now an old man standing at the Jordan River, is the one chanting the song. This revelation is a touching surprise to the viewer, notwithstanding that historically, several biopics have featured their subjects (Custen 1992, p. 58). To be sure, the appearance of an elderly Holocaust survivor must resonate on a different level. There is immense significance to the choice to end the film with the real survivor affirming his commitments to the Jewish covenant of circumcision and to Jewish brotherhood, all the while standing beside Israel's Jordan River, a body of water that is prominently featured in biblical accounts of exiles and returns. Yet, another affirmation in the scene must be acknowledged. The presence of the real-life Perel at the film's end shows not only that the survivor himself lives on, but also that he means to validate the non-survivor Holland's creatively licensed portrayal of his experiences. His willingness to be pictured puts to rest any lingering doubts that the adaptation's vision is authentic in the ways that matter most to him.

Perel's endorsement of the film and presence on the screen matter. As he states at the start of the memoir's preface, "My Holocaust experiences reported here are true. These events actually happened to me" (Perel [1990] 1997, p. ix). He revisits this message soon afterwards in the book's prologue, writing, "I promised myself, and I promise you, the reader, to stick to the truth from beginning to end" (xii). Perel downplays the number of changes that Holland makes to his story, telling an interviewer that only "a few of the scenes in Europa amount to "poetic freedom'," and he also "passionately defends the Polish director, Agnieszka Holland, for producing a movie that is true to the spirit of his wartime experiences" (Engelberg 1992, p. C15). Holland, too, minimizes her own influence on the adaptation by insisting that Europa Europa maintains almost complete fidelity to 
the survivor's true experience. As she states in an interview, "I tried not to invent things too much. Ninety percent of what you see is what Solly said happened" (Tibbetts 2008, p. 137). However, a simple comparison of details between the book and the film reveals that Holland's estimation of her fidelity to Perel's account is far too high. The date of the protagonist's birthday, the death of his sister, and the circumstances of his separation from his brother are portrayed quite differently in the adaptation. Most importantly, circumcision is given far more attention on the screen. The numerous changes to the details of Perel's testimony amount to far more than $10 \%$ of the film's content.

Whatever the exaggerations regarding the fidelity of biographical facts, Perel is correct to assert that the film matches the Jewish spirit of the memoir and the quest for the Jew's voice to be heard. Both the film and the memoir emphasize Jewish religious concepts while resisting sanitization, exploitation, and denial of the Shoah; in other words, the Jewish voice prevails against that of the Nazis. This dynamic should be seen as of paramount importance to any artistic representation of the Shoah, but especially to a visual medium. Unlike literary sources, film adaptations necessarily employ imagery. Transformation from word to image has always fueled debate in adaptation studies (Leitch 2007, p. 178) and is even more hotly contested when the subject is the Shoah. This is understandable when the cinema's role in Holocaust history is considered. Ruth Wisse writes that "the destruction of the image of the Jews has always been the necessary precondition for physical attacks upon them" (Wisse 1992, p. 129). The Nazis' infamous reliance on antisemitic propaganda films, such as Fritz Hippler's Der ewige Jude (Hippler 1940) and Veit Harlan's Jud Süß (Harlan 1940), as a precursor to mass murder lays a problematic foundation for filmmakers, even decades later.

Hitler himself is tied to the use of the cinema of the Third Reich to disseminate Nazi ideas. As one scholar recently writes, "Hitler regarded the representation of Nazism in celluloid as a gift to the future" (Niven 2018, p. 3) and "used the cinema in a variety of ways to promote Nazism" (p. 5). Tony Barta designates the way the Nazis manipulated Hitler's image through film as a dangerous sort of everlasting screen adaptation: "Hitler recognized that military marching and music was ready-made for a medium that loves a spectacle. His screen adaptation would have no competitor in action, content, and plot, and it would be the latest in modern fascist style" (Barta 1998, p. 131). As part of this legacy, even well-intentioned films have too often succumbed to giving voice to Hitler's worldview, which always comes at the expense of Jewish voices. That is, Hitler's crafted image as a commanding, charismatic figure from history is permitted to occupy a more attractive space than his antisemitic message deserves. The concentration camps and killing centers may be liberated, but Hitler's sentiments regarding the Jews live on, having found ways to thrive in the movies. Holocaust adaptations have suffered on the screen at least partly because Hitler possessed a genius for adapting his story in a manner that could entrance audiences for generations. He understood that audiences throughout Western civilization would welcome narratives that could provide an escape from acknowledging, and thus having to act in response to the crimes against the Jew. Adaptations of survivor testimony must take special care to carry the Jew's words, for failing to do so inevitably bolsters the Nazi call to eradicate that which is Jewish in the world. The Jewish survivor should not be eclipsed in art that ostensibly tells his story.

Europa Europa ultimately succeeds in presenting a model for how artists can and should avoid that sort of eclipsing of the Jewish presence and voice. At least some of the survivor's burden, having been picked up by the adapter, is ably transmitted to the filmgoer. It is the burden of exile and persecution, which calls out to the viewer to see the Shoah through the Jew's eyes and to fight against antisemitism and racial hatred in the post-Holocaust world. In this sense, Holland's cutting and shaping of Perel's testimony, as well as her directing of the viewer's attention towards Nazism's systematic assault on the Jewish covenant, may rightly be understood as an attempt at circumcision of popular Holocaust memory. Insomuch as the sharing of testimony succeeds in calling us to action 
against the Nazi voice wherever it surfaces, a covenant between the filmmaker, the survivor, and the viewer is inscribed into the flesh and the heart.

Funding: This research received no external funding.

Conflicts of Interest: The author declares no conflict of interests.

\section{References}

Avisar, Ilan. 1988. Screening the Holocaust: Cinema's Images of the Unimaginable. Bloomington: Indiana University Press.

Baron, Lawrence. 2005. Projecting the Holocaust into the Present. Lanham: Rowman \& Littlefield.

Barta, Tony. 1998. Film Nazis: The Great Escape. In Screening the Past: Film and the Representation of History. Edited by Tony Barta. Westport: Praeger, pp. 127-48.

Bartov, Omer. 2005. The Jew in Cinema: From the Golem to Don't Touch My Holocaust. Bloomington: Indiana University Press.

Confino, Alon. 2014. A World Without Jews: The Nazi Imagination from Persecution to Genocide. New Haven: Yale University Press.

Custen, George F. 1992. Bio/Pics: How Hollywood Constructed Public History. New Brunswick: Rutgers University Press.

Doneson, Judith. 2002. The Holocaust in American Film, 2nd ed. Syracuse: Syracuse University Press.

Eilberg-Schwartz, Howard. 1992. People of the Body: Jews and Judaism from an Embodied Perspective. Albany: State University of New York Press.

Engelberg, Stephen. 1992. A Life Stranger Than the Movie, 'Europa Europa,' Based on It. New York Times, February 19. Available online: https:/ / www.nytimes.com/1992/02/19/movies/a-life-stranger-than-the-movie-europa-europa-based-on-it.html (accessed on 8 November 2020).

Geller, Jay. 2007. On Freud's Jewish Body: Mitigating Circumcisions. New York: Fordham University Press.

Gilman, Sander. 1991. The Jew's Body. New York: Routledge.

Harlan, Veit dir. 1940. Jud Süß. Berlin: Terra-Filmkunst.

Hinson, Hal. 1991. Europa, Europa: Caught in the Act of Survival. Washington Post, August 9. Available online: https://www. washingtonpost.com/wpsrv/style/longterm/movies/videos/europaeuroparhinson_a0a6d7.htm (accessed on 5 October 2020).

Hippler, Fritz dir. 1940. Der ewige Jude. Berlin: Deutsche Filmherstellungs- und- Verwertungs- GmbH.

Holland, Agneszka dir. 1990. Europa Europa. Santa Monica: MGM Home Entertainment.

Insdorf, Annette. 2003. Indelible Shadows: Film and the Holocaust, 3rd ed. Cambridge: Cambridge University Press.

Isser, Edward. 1997. Stages of Annihilation: Theatrical Representations of the Holocaust. Madison: Fairleigh-Dickinson University Press.

Lang, Berel. 2000. Holocaust Representation: Art within the Limits of History and Ethics. Baltimore: Johns Hopkins University Press.

Leitch, Thomas. 2007. Film Adaptation and its Discontents: From Gone with the Wind to The Passion of the Christ. Baltimore: The Johns Hopkins University Press.

Levi, Primo. 1996. Survival in Auschwitz. Translated by Stuart Woolf. New York: Simon \& Schuster. First published 1958.

Loshitzky, Yosefa. 1997. Introduction. In Spielberg's Holocaust: Critical Perspectives on Schindler's List. Edited by Yosefa Loshitzky. Bloomington: Indiana University Press, pp. 1-17.

Marcus, Millicent. 1999. Pasolini's Decameron: Writing with Bodies. In Film and Literature: An Introduction and Reader. Edited by Timothy Corrigan. Upper Saddle River: Prentice Hall, pp. 286-305.

Niven, Bill. 2018. Hitler and Film: The Führer's Hidden Passion. New Haven: Yale University Press.

Patterson, David. 1998. Sun Turned to Darkness: Memory and Recovery in the Holocaust Memoir. Syracuse: Syracuse University Press.

Perel, Solomon. 1997. Europa Europa. Translated by Margo Bettauer Dembo. New York: John Wiley \& Sons. First published 1990. Europa Europa. Paris: Editions Ramsay.

Rosenfeld, Alvin. 1980. A Double Dying: Reflections on Holocaust Literature. Bloomington: Indiana University Press.

Rosenfeld, Alvin. 2011. The End of the Holocaust. Bloomington: Indiana University Press.

Skloot, Robert. 1988. The Darkness We Carry: The Drama of the Holocaust. Madison: University of Wisconsin Press.

Tibbetts, John C. 2008. An Interview with Agnieszka Holland: The Politics of Ambiguity. Quarterly Review of Film and Literature 25: 132-43. [CrossRef]

Wisse, Ruth. 1992. If I Am Not for Myself: The Liberal Betrayal of the Jews. New York: The Free Press. 